\title{
THE EFFECT OF CATHOLIC SECONDARY SCHOOLING ON EDUCATIONAL ATTAINMENT
}

Derek Neal

Working Paper 5353

\author{
NATIONAL BUREAU OF ECONOMIC RESEARCH \\ 1050 Massachusetts Avenue \\ Cambridge, MA 02138 \\ November 1995
}

I gratefully acknowledge support by the John M. Olin Foundation through its grant to the Center for the Study of the Economy and the State and through the Olin Faculty Fellowship. I also thank the Center for Social Program Evaluation for research assistance. I owe special thanks to Hide Ichimura and Jim Heckman for helpful discussions. I also thank John Cochrane, Brian Tyler, Lisa Lynch, Jeff Grogger, Steve Rivkin and Ken McLaughlin for helpful comments. I thank workshop participants at Columbia University, Depaul University, the University of Kentucky, and the University of Virginia for their comments. An earlier version of this paper appeared as CSES working paper number 95. This paper is part of NBER's research program in Labor Studies. Any opinions expressed are those of the author and not those of the National Bureau of Economic Research.

(C) 1995 by Derek Neal. All rights reserved. Short sections of text, not to exceed two paragraphs, may be quoted without explicit permission provided that full credit, including $\odot$ notice, is given to the source. 


\title{
THE EFFECT OF CATHOLIC SECONDARY \\ SCHOOLING ON EDUCATIONAL \\ ATTAINMENT
}

\begin{abstract}
Using data from the National Longitudinal Survey of Youth, this paper provides a detailed analysis of the effect of Catholic secondary schooling on high-school graduation rates and also examines Catholic schooling's effect on college graduation rates and future wages. The paper uses data from the National Catholic Educational Association and the Survey of Churches and Church Membership to construct measures of access to Catholic secondary schooling for each county in the United States. These measures of access provide potential instruments for Catholic school attendance.

The results indicate that Catholic secondary schools are geographically concentrated in urban areas and that Catholic schooling greatly increases educational attainment among urban minorities. The gains from Catholic schooling are modest for urban whites and negligible for suburban whites. Related analyses suggest that urban minorities benefit greatly from access to Catholic schooling primarily because the public schools available to them are quite poor.
\end{abstract}

Derek Neal

Department of Economics

University of Chicago

1126 East 59th Street

Chicago, IL 60637

and NBER 
I. Introduction

Since the early $1980^{\prime} \mathrm{s}$, numerous studies have sought to quantify the effects of private schooling on student achievement. For the most part, these studies contrast the performance of public and Catholic secondary schools. Catholic schools constitute a large relatively homogeneous sector in the private school market, and several data sets provide detailed information concerning secondary schooling and various measures of student achievement. 1

In the existing literature on Catholic schools, achievement test data often serve as measures of school output, but whether school output is measured by test scores, post-secondary educational achievement, or student earnings, Catholic school students perform better, on average, than observationally similar students in public schools. This pattern is clear, but numerous studies offer different explanations for the results. In their analysis of achievement test data from the High School and Beyond Survey, Coleman, Hoffer, and Kilgore (1982) claim that the selection of superior students into Catholic schools cannot

1 Previous studies include work with with the National Longitudinal survey of the High School Class of 1972, the National Longitudinal Survey of Youth, and the High School and Beyond Survey. See Coleman, Hoffer, and Kilgore (1982) and (1987), Cain and Goldberger (1982), Morgan (1983), Murnane, Newstead, and Olsen (1985), Evans and Schwab (1994), Tyler (1994), and Sander and Krautmann (1995). 
fully account for the superior achievement of Catholic school students, and they present their results as evidence that Catholic schools are more effective than public schools. However, Goldberger and Cain (1982), Noell (1982), Murnane, Newstead, and Olsen (1985) and others argue that Coleman, Hoffer, and Kilgore's empirical methodology does not include appropriate controls for selection bias, and that, given appropriate controls for selection, the HSB data provide little evidence of a significant causal relationship between Catholic schooling and student achievement. 2

In this paper, I provide a detailed analysis of the effect of Catholic secondary schooling on high-school graduation rates. I also examine Catholic schooling's effect on college graduation rates and subsequent wages. MY work improves upon previous attempts to control for selection bias by employing new data sources. The National Catholic Educational Association (NCEA) provides directories that give the address and enrollment of every Catholic

2 Coleman and Hoffer (1987) provide additional support for their position with an analysis of achievement growth between the sophomore and senior year of high school. Holding sophomore scores and family background constant, Catholic school seniors performed better then public school seniors.

In their analyses of achievement test data from the High School and Beyond Survey, Murnane, Newstead, and olsen (1985) provide evidence that blacks and hispanics benefit from Catholic schooling but offer little support for the claim that whites benefit from Catholic schooling. The results presented here support the hypothesis that minorities receive the most substantial benefits from Catholic schooling. 
school in the United States, and the Survey of Churches and Church Membership provides the total number of adherents for most religious denominations by county. I use data from these sources and the 1980 census to construct measures of access to Catholic secondary schooling for each county in the United states and then merge this information with individual records from the National Longitudinal Survey of Youth. These measures of access provide potential instruments for Catholic school attendance.

The NCEA data are important in their own right because they provide valuable descriptive information about catholic schools. Coleman, Hoffer, and Kilgore (1982) claim that Catholic secondary schools are relatively rare in urban areas, and that "private education appears at its competitive strongest in the suburbs." ${ }^{3}$ This claim is incorrect. By any reasonable definition, most Catholic secondary schools are located in urban areas, and, on average, urban catholic schools report larger enrollments than their suburban counterparts.

These are important facts. Before we can know how much Catholic school students benefit from access to Catholic schools, we must know what public school alternatives are available to them. Below, I present separate analyses of Catholic school effects for four different sub samples. The samples are divided according to race and type of

3 See Coleman, Hoffer, and Kilgore (1982), p. 23. 
community. 4 The results suggest that, regardless of race, the tangible gains from Catholic schooling are quite small for suburban students. Further, the overall gains from Catholic schooling appear to be quite modest for urban whites.

However, the benefits of Catholic schooling are great for urban minorities. Among urban blacks and hispanics, the probability of high school graduation rises from .62 to at least .88 when the representative public school student is placed in a catholic high school. In addition, urban minorities who attend Catholic schools can expect higher graduation rates from college and higher future wages.

Why are the results so striking for urban minorities? Is it because urban minorities attend the best Catholic schools? The results presented here point to a different answer. Urban minorities receive significant benefits from Catholic schooling because their public school alternatives are substantially worse than those of whites or other minorities that live in rural or suburban areas.

4 Both Evans and Schwab (1994) and Sander and Krautmann (1995) conclude that Catholic schooling raises graduation rates. However, these studies estimate a single catholic school effect. They do not define Catholic school effects with reference to public schools in a particular type of community. 
II. ACCESS TO CATHOLIC SCHOOLS

The NCEA publishes an annual directory of all catholic schools in the United States. I use the 1978-79 directory to construct the population of Catholic secondary schools. Table I presents both Coleman, Hoffer, and Kilgore's (1982) descriptive statistics concerning Catholic secondary schools and statistics taken from the NCEA population. The contrast is striking. The Coleman, Hoffer, and Kilgore figures give an extremely misleading impression about the prevalence of urban Catholic High Schools. To begin, given their definition of urban, Coleman, Hoffer, and Kilgore underestimate the number of urban schools. Further, their definition of urban is quite restrictive. Because they designate all areas within Standard Metropolitan Statistical Areas but outside SMSA Central Cities as suburban, the urban category in Table I does not include Catholic secondary schools in Chelsea, MA, Yonkers, NY, Camden, NJ and other independent cities that border large central cities.

In addition, the data in Table I do not illustrate the high concentration of Catholic secondary schools in large cities. Table II documents the contribution of ten major cities to the overall population of Catholic secondary schools during the 1978-79 school year. These ten cities account for more than one fifth of the students in Catholic secondary schools, and even more striking, $14 \%$ of Catholic secondary students attend school within the city limits of 
New York, Chicago, or Philadelphia.

Table III provides more information about the population of Catholic secondary students. To construct this Table, I merged NCEA data with data on county population levels from the 1980 census. In 1980 , there were 25 counties with at least one million residents. Although these counties accounted for about one fifth of the United states population, Catholic schools in these counties accounted for approximately one third of the total enrollment in Catholic secondary schools. Further, Catholic schools in counties with more than a quarter of a million persons accounted for almost four fifths of the total secondary enrollment. It is doubtful that all of these schools are in or near cities because many counties contain both large urban and suburban populations. However, Table III reinforces the point that most Catholic schools are located in heavily populated areas.

The empirical work below highlights results from the sample of students who live in counties with at least a quarter of a million people. Since most Catholic school students live in these counties, the results document comparisons between public and Catholic schools in the types of communities where catholic schools are most prominent. 
III. A MODEL OF SCHOOL CHOICE

To fix ideas about estimating school effects, consider the following model of school choice. There are two schools, P (public) and C (Catholic). students may attend school $P$ at no cost, but must pay tuition, $t_{c}$ ' to attend school $C$. Each household $i$ has one child and a utility function defined over three goods.

$$
U_{i}=U\left(Y_{i}, E C_{i}, M_{i}\right)
$$

$Y$ is an outcome associated with the child's schooling. EC represents unobserved consumption goods that are a product of the child's schooling. For example, families may value the religious or moral instruction provided by schools even if the instruction does not directly affect the outcome measure $Y . \quad M$ is a composite commodity with a price normalized to one. Preferences are strictly monotonic. i indexes households.

Assume that the outcome is determined as follows:

(2) $\quad \mathrm{Y}_{\mathrm{ip}}=\mathrm{X}_{\mathrm{i}} \beta_{\mathrm{p}}+v_{\mathrm{i}}$ if household $\mathrm{i}$ chooses school $\mathrm{P}$.

(3) $\quad Y_{i c}=x_{i} \beta_{c}+\gamma+\varepsilon_{i c}+\nu_{i}$ if household $i$ chooses school

$x_{i}$ is a vector of demographic characteristics. $\varepsilon_{i c}$ captures the idiosyncratic match between the ith household and 
Catholic schooling. This match may be interpreted as a deviation from, $\gamma$, the mean outcome effect associated with Catholic schooling. $v_{i}$ is an unobserved household specific effect. Assume that $E\left(\varepsilon_{i c} \mid x_{i}\right)=0$ and $E\left(v_{i} \mid x_{i}\right)=0$. Given this framework, the change in utility associated with choosing school $C$ instead of school P, is given by:

$$
\Delta U_{i}=G\left(Y_{i p}, Y_{i c}, E C_{i p}, E C_{i c}, t_{c}, W_{i}\right)
$$

Equation (4) states that the change in utility is a function of outcome measures, educational consumption levels, and consumption of the composite commodity $M$. Note that, given a household's school choice, tuition $t_{c}$ and household income $W$ determine the consumption of the composite commodity $M$.

Assume that a researcher wishes to estimate the Catholic school effect, $\gamma$, given household data on the outcome measure $Y$, demographic characteristics $X$, and an indicator variable $I_{C} \cdot I_{c i}=1$ if household $i$ chooses $C$, and $I_{c i}=0$ if household $i$ chooses $P$. Further, assume that $\beta_{c}=\beta_{p} \cdot 5$ Equation (4) highlights the primary obstacle. The utility gain from choosing $\mathrm{C}$ is an increasing function of $Y_{i c}$, which includes $\varepsilon_{i c^{*}}$ since households with a comparative advantage in school $c$ are most likely to choose

5 This assumption is restrictive, but I need more data to precisely estimate a fully interacted model. The NLSY data contain less than 350 urban Catholic school students, and I employ approximately 20 controls in the $X$ matrix. 
school $C, E\left(\varepsilon_{i c} \mid X_{i}, I_{c i}=1\right)>0$, estimators of $\gamma$ that do not correct for this source of selection bias will be biased upward. In addition, a bias will also arise if preferences for the educational consumption goods provided by Catholic schools are correlated with unobserved characteristics that enhance the outcome measure, $E\left(v_{i} \mid x_{i}, I_{C i}=1\right)>0$.

Potential Instruments

The task of forming a consistent estimator for $\gamma$ becomes manageable if one can construct instruments for $I_{c}$. Taken together, equations (2)-(4) point to several potential instruments for Catholic school attendance. Note that educational consumption levels enter equation (4), but they do not enter the outcome equations. Several previous studies use religious affiliation as an instrument for Catholic schooling. The rationale is that household demand for Catholic religious instruction should influence Catholic school attendance but may not affect student performance.

However, using religious affiliation as an instrument for Catholic school attendance may be problematic for several reasons. To begin, it is possible that, within a given population, students from Catholic families expect above average levels of performance whether or not they attend catholic schools. In this case, $E\left(\nu_{i} \mid\right.$ Catholic $)>0$. Further, Catholic students may have a comparative advantage in Catholic schools. Thus, even if $E\left(v_{i} \mid\right.$ Catholic $)=0$, 
$E\left(\varepsilon_{i c} \mid\right.$ Catholic) may be positive. In either case, religious affiliation is not a valid instrument for catholic school attendance, and estimators that rely on this instrument may tend to overstate the effectiveness of Catholic schools.

In the analysis below, I do not rely on religious affiliation as my only instrument for Catholic schooling. Using the National Catholic Education Association data and the Survey of Churches and Church Membership, I construct two measures of Catholic school availability for every county in the United States.

The first measure expresses local Catholic church adherents as a fraction of county population in 1980 . Hoxby (1993) provides evidence that Catholic secondary schools receive greater subsidies and subsequently charge lower tuitions in areas with large Catholic populations. Thus, the population density of Catholics in a given locality may provide a valid instrument for Catholic school attendance. The model above clearly shows that tuition, $t_{c^{\prime}}$ affects school choice but does not enter the outcome equation.

The second instrument is Catholic secondary schools per square mile. Since most public school systems provide free bus service, transportation costs also affect the marginal costs of attending Catholic schools, and these costs should be inversely related to the geographic density of Catholic schools. 
As a final comment on model specification, I must note that the model described above and much of the empirical work below involves an important maintained assumption. In this framework, the location of the household is fixed. Households do not choose their location. They simply choose between two available schools. In reality, households choose schools and locations simultaneously, and this fact complicates the analysis in several ways. 6

As an illustration, consider a world with two communities. The first offers only public schools. The second offers both public and Catholic schools, - but the public schools in the second community are inferior to those in the first. If agents are free to choose both location and school, how does one define a "Catholic School Effect" for a given outcome measure? Is the counter factual defined by transfers of students between Catholic schools and their public school neighbors or by transfers between Catholic schools and the superior public schools in the other community?

Throughout most of this paper, I am concerned with a Catholic school effect that is analogous to the former. I restrict the sample to persons who live in urban areas, and

6 See Tyler (1994) for an explicit model of private school effects when residential choice is endogenous. 
I also control for the demographic characteristics of each area. My goal is to measure performance differences between public schools and Catholic schools in urban areas taking the population of urban students as given. Further, I divide the sample by race because public school systems within a given urban area may be quite segregated by race.

IV. EMPIRICAL RESULTS

The data on student characteristics and outcomes comes from the National Longitudinal survey of Youth. The NLSY is a panel survey that follows 12,686 young people who were between 14 and 21 years of age in 1978. In 1979, the survey asked students whether they attended a public or private high school. The NLSY also conducted High school surveys and retained a record of $\mathrm{High}$ school affiliation for 8,204 of the respondents.

If the school survey records that a given respondent attended Catholic school, I call that respondent a Catholic school student. In addition, if the school survey records no information about High school affiliation and the respondent reports attending a private school, I label the respondent a Catholic school student. If the school survey records that the respondent attended a non-Catholic private school, I delete the respondent from the sample. 7

7 My strategy likely overstates the number of Catholic 
In the balance of the paper, I define urban counties as counties with more than a quarter of a million people. Counties with less than a quarter of a million residents are labeled suburban. I focus the analyses primarily on student outcomes in the urban counties for two reasons. First, as Table III indicates, the vast majority of catholic school students attend school in counties with more than a quarter of a million people. Second, in preliminary analyses, I found little evidence that catholic school effects are significant in suburban counties.

To begin, I present results from univariate probit models of high school graduation. 8 Table IV presents the results for four sub samples. The samples are divided by

school students because I am imputing catholic for all unknown private school affiliations. However, false imputations should be rare. The reported affiliations indicate that Catholic schools account for over 808 of the students in the private sector, and in counties with more than 250,000 residents, the corresponding figure is $87 \%$. Further, false imputations should lead to an understatement of the effect of Catholic schooling on graduation rates. Coleman and Hoffer (1987) report that drop out rates are lower in Catholic schools than in other private schools. See Morgan (1983) for more information about the NLSY school survey information.

8 High school graduates are defined as individuals with a high school diploma. GED recipients do not count as graduates.

The NLSY data include test scores from the Armed Forces Vocational Aptitude Battery. I do not present analyses of these test scores. When the tests were administered to the NLSY sample, many respondents had been out of high school for several years. Thus, analyses of Catholic schooling's effects on these scores would have to incorporate models of individual activities following high school that affect test performance. 
race, and they are further divided into students from either urban or suburban counties. 9

Note that the estimated effect of Catholic schooling on graduation rates is not the same across the four sub samples. For suburban students of all races, there is little evidence of a significant effect of Catholic schooling on graduation rates. However, this is not true for urban students. Among white urban students, the public school graduation rate is .75 . According to the results in Table IV, the probability of graduation rises to .85 if a representative public school student transfers to an urban Catholic school. 10 Among urban minorities, the public school graduation rate is .62 . Taking this rate as a benchmark, the estimated Catholic school effect for urban minorities implies an enormous increase - from .62 to .88 - in the probability of graduation. 11

9 The white sample contains all respondents who are not black or hispanic.

10 Throughout the paper, I evaluate the estimated impact of catholic schooling on graduation probabilities by considering the transfer of a representative public school student to a Catholic school. The student is representative in the sense that her predicted probability of graduation, conditional on public schooling, equals the public school graduation rate.

11 Murnane, Newstead, and olsen's (1985) results suggests that hispanics may gain more from Catholic schools than blacks. I do not perform separate analyses for these two groups because the NLSY provides few records of minority students attending Catholic schools. There are less than 150 in the whole sample. Given these data, I cannot detect a statistically significant differences between catholic school effects for hispanics and Catholic school effects for blacks. 
Controlling for Selection Bias

The results in Table IV indicate significant effects of Catholic schooling on high school graduation rates for urban whites and dramatic effects for urban minorities. The descriptive statistics in Appendix Table A-1 show that, compared to students in public schools, Catholic school students do come from more advantaged family backgrounds. For example, they are more likely to have two parents, parents with high levels of education, and parents who are professionals. Therefore, it is natural to ask whether or not the results in Table IV indicate real gains from Catholic schooling or simply the selection of students into Catholic schools who are superior with respect to some unobserved traits. I address this question using several variants of the following bivariate probit model.

The white sample includes the NLSY oversample of poor whites. I also performed these analyses on samples that exclude observations from the poor white oversample. The results are quite similar.

Finally, I estimated the high school graduation equations given a control for college preparatory curriculum. Among urban whites, this control leads to a modest decrease in the estimated Catholic school effect. Among urban minorities, the estimated effect of catholic schooling on graduation probabilities is approximately the same with or without this additional control. Coleman, Hoffer, and Kilgore (1982) argue that curriculum controls are inappropriate because they reflect school policies not inherent student characteristics. 


$$
\begin{gathered}
h_{i}=x_{i} \beta+I_{c i} \gamma+\eta_{h i} \\
c_{i}=z_{i} \alpha+\eta_{c i}
\end{gathered}
$$

For student $i, h_{i}$ is the latent value of graduating from high school and $c_{i}$ is the latent value of attending $a$ Catholic school. $X$ is a set of student characteristics. $z$ includes the student characteristics in $x$ and $a$ set of instruments for Catholic school attendance. We observe $I_{h i}$ $=1$ if $h_{i}>0$ and $I_{h i}=0$ if $h_{i}<0$. We observe $I_{c i}=1$ if $c_{i}>0$ and $I_{c i}=0$ if $c_{i}<0$. Assume that both $\eta_{h i}$ and $\eta_{c i}$ are mean zero, given $x_{i}$ and $z_{i}$, and that they are distributed bivariate standard normal.

This empirical model closely resembles the model of school choice outlined in section III. Suppose household utility functions characterize the preferences of the parents. Further, assume that parents care about both the pecuniary and non-pecuniary returns their child receives from schooling. Parents cannot control these returns, but they can affect the distribution by providing educational resources in the home and by choosing their child's school. Given the parent's school choice, the match between school and child determines the potential returns from schooling, and the child completes school if the net gains from doing so are positive. In equation (5), $h_{i}$ represents the net gains from completing high school. The parameter $\boldsymbol{\gamma}$ captures an innovation in these gains that comes from attending 
Catholic rather than public schools.

In section III, I discussed three possible instruments for Catholic school attendance. The first is individual religious affiliation. The second and third are catholic adherents as a fraction of the local population and Catholic schools per square mile. Both of the later are measured at the county level.

A key concern is whether or not these variables are correlated with the error term in the high school graduation equation. As I note in section III, this error term has two components. The first captures individual specific unobservables that affect the probability of graduation. For those who attend Catholic schools, a second eomponent captures the idiosyncratic match between the student and Catholic schooling. Here, I examine a restricted version of the original model. I assume that the expected value of the match specific component is zero for all students, but I entertain the possibility that the individual specific component is correlated with Catholic school attendance.

Thus, in considering the validity of the proposed instruments, I am concerned about possible correlations between the instruments and unobserved factors that may affect individual graduation probabilities. For example, students from Catholic families might be generally more likely to complete high school than observationally similar students who are not Catholic. Further, the two measures of Catholic school availability may be correlated with 
location-specific variables that influence the value of completing high school.

I explore these issues by estimating univariate probit models of high school graduation on the samples of urban public school students. Conditional on observed student characteristics, I interpret significant correlations between public school graduation rates and potential instruments as evidence that the instruments in question should not be excluded from the graduation equation in the corresponding bivariate model. 12

The results, in Table $\mathrm{v}$, indicate that among white students from similar backgrounds, graduation rates are slightly higher for students who live in counties with relatively large Catholic populations. ${ }^{13}$ However, conditional on the size of the local catholic population, we cannot reject the null hypothesis that the other two potential instruments do not affect graduation probabilities for public school students. Among blacks and hispanics, the story is different. Here, there is a negative correlation

\footnotetext{
12 These analyses are not formal specification tests. The results do not permit direct inferences about population relationships because the analyses include only public school students. However, the results do provide suggestive evidence concerning potential exclusion restrictions. Below, I present likelihood ratio tests of the restrictions indicated by the results.

13 Take the sample average of .75 as a benchmark graduation rate. The estimated coefficient implies that a one standard deviation increase in the population density of Catholics raises the expected graduation rate for urban whites in public schools to almost .79.
} 
between expected graduation rates and the geographic density of Catholic secondary schools, but conditional on Catholic schools per square miles, there is no statistically significant relationship between the public school graduation rates and either religious affiliation or the local population density of catholics. ${ }^{14}$

Thus, I estimate two separate versions of the bivariate probit model described in equations (5) and (6), one for urban minorities and one for urban whites. In the analysis of minority students, I exclude religious affiliation and local Catholic population density from the graduation equation. In the analysis of white students, I exclude religious affiliation and Catholic schools per square mile.

Results from alternative specifications provide support for my choice of exclusion restrictions. For both the white and minority samples, I performed a joint test of the relevant exclusion restrictions, and $I$ also tested each restriction separately. In all six cases, I was not able to reject the restrictions. ${ }^{15}$ In addition, the results in Table

14 Take the sample average of .62 as a benchmark graduation rate. The estimated coefficient implies that a one standard deviation increase in the geographic density of Catholic schools lowers the expected graduation rate for urban minorities in public schools to .58 .

15 The joint tests are likelihood ratio tests. The other tests are $t$ tests. In four of the six tests, the $p$ values are well over .5. The $p$ values for the remaining two are .37 and .18 . The .18 value corresponds to the test of the hypothesis that local Catholic population density should be excluded from the minority equation. As the notes to Table VI explain, the estimated Catholic schooling effect is both 
VI provide support for my decisions to include Catholic population density in the white graduation equation and Catholic schools per square mile in the minority graduation equation. In each case, the additional control in question is significantly correlated with graduation rates.

The estimated coefficients in Table VI provide no evidence that the graduation effects reported in Table IV are driven by the selection of superior students into Catholic schools. In both models, the estimated correlation between the two errors is negative although not statistically significant. Further, the coefficient estimates from these bivariate analyses imply even larger graduation effects from Catholic schooling. 16

The estimated Catholic schooling effects reported in Table VI are quite robust to various choices of exclusion restrictions. In both the minority and white samples, alternative specifications that relax one or both of the relevant exclusion restrictions yield estimated Catholic schooling effects that are quite similar to those reported in Table VI. 17 The notes to Table VI describe the results in

larger and more statistically significant when this variable is included in the minority equation.

16 The results from Table VI imply that, in the minority sample, Catholic schooling raises the probability of graduation from .62 to .92 for the representative public school student. In the white sample, Catholic schooling raises the probability of graduation from .75 to .92 .

17 For minorities, all three alternative specifications produce larger estimated effects of Catholic schooling on 
detail.

Nonetheless, it is important to remember that these analyses do not address the problems that arise from selection on the match specific component of $\eta_{i h}$. Holding scholastic aptitude constant, students with little knowledge of Catholicism or students from religious traditions other than Catholicism may be poorly matched with catholic schooling. Thus, religious affiliation may provide information about a student's comparative advantage in Catholic schooling even it is uncorrelated with general academic aptitude. ${ }^{18}$ The same can be said for my measures of Catholic school availability. Holding religious affiliation constant, these measures may serve as proxies for student

graduation rates. However, the differences between these estimated effects and those reported in Table VI imply differences in predicted graduation rates of less than three percentage points. For whites, two of the alternative specifications yield smaller estimated Catholic schooling effects and one yields larger effects, but in all three cases the differences imply absolute changes in predicted graduation rates of roughly one percentage point.

18 In unreported analyses, I re-estimated the high-school graduation equations adding a term for an interaction between Catholic school attendance and Catholic religious status. I also estimated the bivariate probit models using only samples of urban Catholics. Neither analysis provided evidence that Catholics benefit more from Catholic schooling. However, it would be hard to detect such an effect in the NLSY data. These data provide few records of non-Catholics attending Catholic schools. Roughly $90 \%$ of the white Catholic school population reports Catholic as their religious affiliation. Among minorities, the corresponding figure is $75 \%$.

See Heckman and Robb (1985) for a formal analysis of treatment effects in the presence of matching between subjects and treatment. 
knowledge of and familiarity with Catholicism.

If my instruments are correlated with the match specific component of the graduation error term, the estimates from the bivariate model likely overstate the increase in graduation rates that would be observed in a random sample of public school students who were exogenously transferred to Catholic schools. Nonetheless, the results clearly indicate that Catholic schools do raise graduation rates for their own students, and this is especially true for minority students. None of the results support the hypothesis that Catholic school students graduate more often simply because they are better with respect to some unobserved traits.

Why Are The Gains For Urban Minorities So Large?

In Table IV, the probit model of high school graduation indicates an enormous effect of catholic schooling on high school graduation probabilities for urban minorities. The results from the bivariate analysis in Table VI imply even larger effects. Why do the benefits of catholic schooling appear so great for urban minorities? It is possible that urban minorities attend the best Catholic schools, but Table VII points to a different answer.

Table VII gives predicted graduation probabilities for public school students according to the population of their county of residence. The predictions are given holding 
student characteristics constant, and the analyses are performed separately for whites and minorities.

The difference between the two sets of results is quite striking. In counties with less than one million persons, there are small differences between the predicted graduation probabilities for minorities and whites. However, in counties with more than one million persons, the difference is .10. It appears that the relative quality of the public schools available to minorities in large counties is quite poor. 19

This result helps us understand the large estimated Catholic school effects for urban minorities. Throughout the previous analyses, the urban sub samples-contain students from counties with more than 250,000 persons. According to Appendix Table A-1, 55\% of urban minorities in Catholic schools and $45 \%$ of the urban minorities in public schools live in counties with more than one million residents. Thus, comparisons between Catholic and public school students in large counties and probably large cities

19 The notes at the bottom of Table VII provide details concerning the construction of these predicted graduation rates.

Some may interpret these results as evidence that unobserved differences between whites and minorities are greater in large cities. However, this position is hard to reconcile with the following result: within the catholic sector, there is no relationship between county size and graduation rates or racial differences in graduation rates. Further, in analyses restricted to minority students from counties with more than one million residents, I found no evidence of positive selection into Catholic schools. As in Table VI, there is weak evidence of negative selection. 
contribute significantly to the reported Catholic school effects for minorities in Tables IV and VI. 20

I have also analyzed differences in graduation rates within the catholic sector. Minority graduation rates in Catholic schools vary little with county size, and this result holds with and without controls for student characteristics. The same cannot be said for minority graduation rates in public schools. Table VII provides evidence that urban minorities receive great benefits from Catholic schooling primarily because their local communities offer poor public school alternatives.

Does Negative Selection Make Sense?

In both bivariate probit models presented in Table VI, the estimated correlation between the error terms in the two equations is negative although statistically insignificant. In unreported analyses on the pooled sample of urban whites and minorities, the estimated correlation is both negative and significant. Further, several other recent studies of

20 I also estimated a separate high school graduation equation for minorities in counties with more than one million residents and another for minorities in counties with between 250,000 and one million residents. Although the estimated Catholic school effects in both equations are positive and statistically significant, the estimate from the former implies a larger change in expected graduation rates. Nonetheless, given the small samples sizes, the difference between the two estimated effects is not statistically significant. 
Catholic school effects report negative selection into Catholic schools. 21

Why might we observe negative rather than positive selection into Catholic schools? It is hard to answer this question without access to more disaggregate data, but I offer the following conjecture. Within a given county, parents who have both considerable financial means and strong preferences for good schools often live in small school districts outside the central city, and they send their children to elite public schools. Therefore, with respect to unobserved traits that enhance academic performance, the best students from upper and middle class homes may not be concentrated in catholic schools but rather in elite public schools. 22

21 Tyler (1994) and Evans and Schwab (1994) also report evidence of negative selection into Catholic schools. Tyler examines data from the National Longitudinal survey of the Class of 1972. Evans and Schwab analyze data from the High School and Beyond Survey.

22 In analyses of achievement data, Greeley (1982) points out that, for most students, Catholic schooling is associated with increased achievement. However, among those who plan to attend college and whose fathers attended college, achievement scores are slightly higher in public schools than Catholic schools. On page 84, Greeley writes, "Presumably the public schools which the offspring of ambitious, college-educated families attend are very different from those which the children of the noncollege educated attend." 
College Graduation Rates

At this point, I must interject a cautionary note concerning the interpretation of these results. These results indicate that, in urban areas, the benefits derived from Catholic schooling exceed those derived from public schooling. These results provide no information about the source of this benefit differential. In any given school, the full cost of graduating is in part a function of student satisfaction with extra-curricular activities, social interactions, safety and other aspects of the school environment. 23 Therefore, the results in Table IV and VI do not rule out the possibility that urban students-actually acquire skills at the same rate regardless of whether they attend Catholic or public schools. Public school students may drop out more often for reasons that do not relate directly to the rate of learning in public schools.

To gain further information about why urban Catholic Catholic secondary students graduate more often than similar public school students, I estimate univariate probit models of college graduation for the two sub samples. One benefit of schooling is learning how to learn. If Catholic schooling develops better learning skills than public

23 Bryk, Lee, and Holland (1993) conduct extensive case studies of several Catholic schools. They claim that Catholic schools excel at fostering a sense of community within schools. 
schooling, Catholic secondary students possess a comparative advantage in careers that involve significant post-secondary education.

Table VIII shows that, among urban students, Catholic schooling is associated with higher graduation rates from college. ${ }^{24}$ Further, this is not purely a high school graduation effect. Even in samples restricted to high school graduates, Catholic secondary schooling appears to significantly increase the probability of college graduation. These results hold for both whites and minorities.

Among urban minorities, the probability of college graduation rises from .11 to .27 when the typical-students attends a Catholic school instead of a public school. Among urban minorities that graduate from high school, the corresponding change is .16 to .30 . For urban whites, the estimated coefficients imply the following changes in college graduation probabilities: .26 to .38 for the full sample, and .31 to .42 for the sample of high school graduates.

These results provide suggestive evidence that urban Catholic school students actually learn more than similar public school students who complete the same amount of formal schooling. Even among samples of high school

\footnotetext{
24 Similar analyses with suburban students show no significant effect of Catholic schooling on college graduation rates.
} 
graduates, we observe significant effects of Catholic secondary schooling on future rates of college graduation. 25

V. PECUNIARY RETURNS TO CATHOLIC SCHOOLING

Catholic secondary schooling does increase the probability of high school graduation for some students. Minority students in urban areas are much more likely to finish high school if they attend a Catholic school instead of a public school, and Catholic schooling is also associated with modest increases in graduation probabilities for urban whites. Further, Table VIII indicates that the benefits of Catholic schooling also lead to higher college graduation rates for urban students.

One suspects that these gains in schooling completion should translate into wage gains in the labor market. 26 Here, I present some preliminary evidence concerning the magnitudes of the wage gains from Catholic schooling. In these analyses, I do not employ instruments. Rather, Table

25 In unreported analyses, I also estimate bivariate probit models of college graduation and Catholic school attendance. These models share the same structure as the high school graduation models in Table $v$. In all cases, the estimated Catholic school effects are positive but imprecisely estimated. The estimated correlations between the error terms in the two equation are always small and statistically insignificant.

26 This issue is of particular interest because recent research on the wage structure indicates that pecuniary returns to education have increased significantly since 1980. See Juhn, Murphy, and Pierce (1993). 
IX displays results from six oLs regressions of log wages on numerous worker characteristics and a dummy variable for Catholic secondary schooling. The wage observations are for men only, and they are taken when the respondents are between ages 27 and 34. Columns (a) through (c) contain results for whites. Columns (d), (e), and (f) present results for minorities.

All specifications include controls for numerous background variables, but the specifications differ in controls for educational achievement. The results in columns (a) and (d) are presented without controls for educational achievement. Those in (b) and (e) are presented with a control for high school graduation only. The remaining specifications provide controls for both high school and college graduation.

The contrast between the results for the two sub samples is striking. Among whites, the wage gains from Catholic schooling are positive but not statistically significant. However, the story is quite different in the minority sample. In the baseline regression, Catholic schooling is associated with an increase in log wages of .314. Conditional on controls for both high school and college graduation, the figure is .234 .

These results for urban minorities likely overstate the wage gains associated with Catholic schooling. Catholic schools are concentrated in areas of the country where the general level of wages is high. Although the regressions 
contain dummies for urban residence, region of residence, and interactions between urban and region, the estimates in Table IX may overstate the effects of Catholic schooling on subsequent wages if these controls do not eliminate location specific components of wages that may be correlated with having attended a Catholic school. 27 Further, to the extent students work in the communities where they grew up, my measures of access to Catholic schools are not valid instruments in wage equations. These measures of access are likely correlated with local costs of living and other sources of geographic variation in wages. 28

Nonetheless, the results do provide some useful information about the wage gains from Catholic schooling. The previous sections of the paper show that urban minorities who attend Catholic school are much more likely to complete both high school and college than are observationally similar students in public schools.

27 without the controls for region, the estimated effects of Catholic schooling on log wages are even larger. For whites, the estimated effects are about $50 \%$ larger without these controls. Because Catholic schools are so prominent in large cities, it is certainly possible that the estimated effects of Catholic schooling on wages would be smaller given finer controls for local cost of living.

28 Attempts to estimate the urban minority wage equations using instrumental variables produced incredibly large estimates of the Catholic school wage effect. This is true using several different sets of exclusion restrictions. In terms of $\log$ wages, the estimates imply a Catholic school wage effect of at least .7. Further, although the estimated coefficients on Catholic schooling were statistically significant in some specifications, the estimated standard errors were quite large in all cases. 
Further, there is little support for the hypothesis that selection bias drives these results. Given these results, I pose the following question: Under the assumption that Catholic schooling affects future wages only through its effect on educational attainment, what would we conclude about the wage gains from Catholic schooling?

Under such an assumption, the estimated effect of Catholic schooling on wages should be zero given controls for educational attainment, and the difference between the estimated coefficients on Catholic schooling in columns (d) and (f) provides an alternative estimate of the Catholic school wage effect. The difference indicates that, for urban minority men, Catholic schooling increases log wages by .08 solely through its effect on educational attainment. ${ }^{29}$ Compared to their public school counterparts, minority students in urban Catholic schools can expect roughly $8 \%$ higher wages in the future simply because they are more likely to complete high school and college. ${ }^{30}$

29 This difference is statistically significant at a confidence level of .0001. The estimated covariance between the two coefficients is .0067 .

30 similar analyses for minority women produce smaller oLs estimates of Catholic wage effect. The unconditional estimate is .13. However, the difference between the unconditional estimate and the estimate conditional on both education controls remains .08 . 
VII. Conclusions

What are the benefits of Catholic schooling? The answer depends critically on the quality of available public school alternatives. The results from Table VII suggest that public school quality deteriorates in urban areas and that this deterioration is most dramatic in minority communities. Consequently, throughout the paper, various analyses consistently indicate that urban minorities enjoy the greatest benefits from Catholic schooling.

In the urban minority sample, Catholic schooling dramatically increases the probability of high school graduation. Further, among those who graduate from high school, Catholic schooling appears to increase college graduation rates. Finally, the wage regressions in rable IX suggest that these gains in educational achievement translate into future wage gains.

For urban whites, the effects are similar in sign but always smaller in magnitude. In fact, for urban whites, the estimated wage gain from catholic schooling is not statistically significant. Further, for suburban students, the NLSY data provide little evidence that catholic schooling provides tangible benefits.

In sum, these results do not indicate that Catholic schools are superior to public schools in general. Rather, they suggest that Catholic schools are similar in quality to suburban public schools, slightly better than the urban 
public schools that white students usually attend, and much better than the urban public schools that many minorities attend.

In this paper, I have not modeled residential choice. This is a shortcoming because many families make simultaneous decisions concerning where they will live and what schools their children attend. However, I expect that my main conclusions will hold in future studies that model residential choice explicitly. I claim that urban minority students benefit most from access to Catholic schools because their local public school alternatives are poor. I suspect that this is especially true among urban minorities who are economically disadvantaged. ${ }^{31}$ For these students, Catholic schools may be an option either because scholarships are available or because their families are able to afford the modest tuitions that are common in Catholic schools, but as Friedman (1962) points out, their families can seldom afford housing in the exclusive neighborhoods with the best public schools.

31 Tyler (1994) presents evidence that the effect of Catholic schooling on wages is greatest in poor urban neighborhoods. Tyler uses zip code data from the NLS72 survey to identify neighborhoods. 


\section{REFERENCES}

Bryk, A., Lee, V., and Holland, P. Catholic Schools and the Common Good. Cambridge, MA: Harvard University Press, 1993.

Coleman, J., Hoffer, T., and Kilgore, S. High School Achievement: Public, Catholic, and Private Schools Compared. New York, NY: Basic Books, 1982.

. Public, Catholic, and Private Schools: The Importance of Community. New York,

NY: Basic Books, 1987.

Evans, W. and Schwab, R. "Finish High School and Starting College: Do Catholic Schools Make a Difference " forthcoming, Quarterly Journal of Economics.

Friedman, M. Capitalism and Freedom. Chicago, IL: University of Chicago Press

Goldberger, A. and Cain, G. "The Causal Analysis of Cognitive Outcomes in the Coleman, Hoffer, Kilgore Report." Sociology of Education, 55 (1982): 103-122.

Greeley, Andrew M. Catholic High Schools and Minority Students. London: Transaction Books, 1982.

Heckman, James and Robb, Richard. "Evaluating The Impact of Treatments on Outcomes." in J. Heckman and B. Singer, eds., Longitudinal Analysis of Labor Market Data, Cambridge London: Cambridge University Press, 1985.

Hoxby, C. M. "Do Private Schools Provide Competition for Public Schools?" unpublished manuscript, M.I.T. (1993).

Juhn, C., Murphy, K., and Pierce, B. "Wage Inequality and the Rise in Returns to Skill." Journal of Politcal Economy 101 (1993): 410-442.

Morgan, W. "Learning and Student Life Quality of Public and Private School Youth." Sociology of Education 56 (1983): 187-202. 
Murnane, R., Newstead, S. and Olsen, R. "Comparing Public and Private Schools: The Puzzling Role of Selectivity Bias." Joumal of Business and Economic Statistics 3 (1985): 2335.

Noell, J. "Public and Catholic Schools: A Reanalysis of Public and Private Schools.'" Sociology of Education 55 (1982): 123-132.

Sander, William and Krautmann, Anthony. "Catholic Schools, Dropout Rates, and Educational Attainment." Economic Inquiry 23 (1995): 217-33.

Tyler, B.S. "An Analysis of Public and Catholic Secondary Education and the Earnings of Men." unpublished dissertation, University of Chicago (1994). 


\section{Geographic Distribution of Catholic Schools 1978-1979 School Year}

Table I

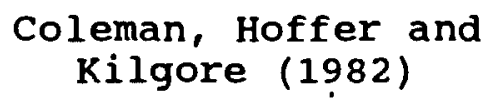

1,860

900,700

Catholic High School students

Catholic High Schools
Both data sets cover the 1978-79 school year. Coleman, Hoffer, and Kilgore (1982) created their statistics using the National Opinion Research Center's School Universe Tape. The National Catholic Educational Association data comes from a directory entitled Catholic Schools in America. The NCEA claims that this directory contains every Catholic school in the United states.

Coleman, Hoffer, and Kilgore (1982) define urban as in a city of at least 50,000 people that is the central city of an SMSA. The urban numbers under NCEA do not reflect the greater than 50,000 population restriction. However, this constraint should effect very few cases.
NCEA

Urban 


\section{Ten Cities with the Most Catholic Secondary Schools 1978-1979 School Year}

Table II

$\begin{array}{lcccc} & \text { Schools } & \begin{array}{c}\text { Cumulative } \\ \text { Percentage }\end{array} & \text { students } & \begin{array}{c}\text { Cumulative } \\ \text { Percentage }\end{array} \\ \text { New York } & 69 & .044 & 52,348 & .060 \\ \text { Chicago } & 47 & .074 & 36,178 & .102 \\ \text { Philadelphia } & 24 & .090 & 30,199 & .137 \\ \text { New orleans } & 20 & .103 & 12,288 & .151 \\ \text { St. Louis } & 18 & .114 & 10,957 & .164 \\ \text { Cincinnati } & 16 & .124 & 12,324 & .178 \\ \text { Detroit } & 14 & .133 & 8,201 & .187 \\ \text { Washington, DC } & 14 & .142 & 5,631 & .194 \\ \text { San Francisco, CA } & 13 & .151 & 6,989 & .202 \\ \text { Los Angeles, CA } & 13 & .159 & 6,233 & .209\end{array}$

Data are taken from Catholic schools in America. The numbers reflect only schools within each city's limits. 
Distribution of Catholic Schools

by County Population Levels

1978-1979 School Year

\section{Table III}

\section{counties}

Population $>1,000,000$

Population $>500,000$

Population $>250,000$

Total
25

84

176

3,132
Schools

413

$26 \%$

285,298

$33 \%$

806

$52 \%$

526,067

$61 \%$

1,072

$69 \%$

681,443

$79 \%$

Here, data from Catholic Schools in America are merged with data from the 1980 census using county fips codes. The population categories refer to county population in 1980. The data on schools comes from the 1978-1979 school year. 
Table IV

URBAN COUNTIES

\section{Whites}

Black

Female

$\begin{aligned} & \text { Mom - High School } \\ & \text { Graduate } \\ & \text { Dad - High School } \\ & \text { Graduate }\end{aligned}$

Mom - College Graduate

Dad - College Graduate

Mom Professional

Dad Professional

Two Parent Family

Numerous Family Reading Materials

No Family Reading Materials

County Population 1980

$500,000-1,000,000$

County Population 1980 :

$>1,000,000$
Blacks \& Hispancis

0.211

$(0.059)$

0.107

$(0.058)$

0.364

$(0.070)$

0.342

$(0.072)$

0.252

$(0.131)$

0.113

(0.100)

0.149

(0.126)

0.234

(0.082)

0.506

$(0.068)$

0.294

$(0.062)$

$-0.600$

(0.148)

$-0.014$

(0.070)

$-0.041$

$(0.075)$

$(0.131)$

(0.129)

$(0.059)$

$-0.240$

(0.080)

$-0.370$

$(0.078)$
NON-URBAN COUNTIES

Whites

Blacks * Hispanics

0.236

(0.079)

0.202

(0.053)

0.206

(0.070)

0.547

(0.062)

0.361

(0.097)

0.277

$(0.063)$

0.366

(0.102)

0.230

$(0.166)$

0.360

(0.312)

0.148

(0.124)

0.411

$(0.328)$

0.120

$-0.127$

(0.124)

(0.213)

0.175

(0.086)

$-0.051$

$(0.213)$

0.403

0.115

$(0.079)$

$(0.061)$

0.197

$(0.060)$

(0.101)

$-0.539$

$(0.097)$

$-0.367$

$(0.082)$ 


\begin{tabular}{|c|c|c|c|c|}
\hline $\begin{array}{l}\text { Percentage of Families } \\
\text { on Welfare - County } 1980\end{array}$ & $\begin{array}{l}-1.524 \\
(0.577)\end{array}$ & $\begin{array}{l}-0.786 \\
(0.418)\end{array}$ & $\begin{array}{l}-1.287 \\
(0.604)\end{array}$ & $\begin{array}{l}0.607 \\
(0.547)\end{array}$ \\
\hline Catholic School & $\begin{array}{l}0.361 \\
(0.120)\end{array}$ & $\begin{array}{l}0.854 \\
(0.177)\end{array}$ & $\begin{array}{l}0.255 \\
(0.202)\end{array}$ & $\begin{array}{l}0.511 \\
(0.431)\end{array}$ \\
\hline Sample Graduation Rate & .76 & .64 & .74 & .70 \\
\hline Attending Catholic Schools & .09 & .05 & .03 & .01 \\
\hline Sample size & 2626 & 2434 & 3110 & 1597 \\
\hline
\end{tabular}

All respondents come from the National Longitudinal survey of Youth. The data do not include respondents from the military subsample because the military uses high school graduation as a criterion for screening applicants. Further, I eliminate respondents if the NLSY data show that they attended a non-Catholic private school. Appendix Table A-1 provides descriptive statistics.

Here, the dummy variables describing parents' traits are coded as one when the parent in question possesses the trait and the respondent knows this to be the case. Otherwise, these variables are coded as zeros. The specifications also contain dummy variables for whether or not the respondent knows the background of each parent.

The 1980 census provides data on county population and welfare rates. The National Catholic Educational Association provides the location of all Catholic secondary schools during the $1978-79$ school year. The 1980 Survey of Churches and Church Membership provides the number of Catholic adherents for each county. The county codes for about 400 NLSY respondents are invalid due to coding errors. These cases are eliminated from the sample. Further, I eliminate a few cases involving localities that are coded differently across data sets. 
Probit Analysis of High School Graduation Public School Students from Urban Counties

Table V

WHITES

BLACKS \& HISPANICS
(A)
(B)
(A)
(B)

Black

$-$

-

.215

(.059)

.205

Female

.120

$(.061)$

.120

(.061)

.286

$(.055)$

(.094)

Mom - High School

.356 Graduate

$(.072)$

.353

$(.075)$

.255

$(.067)$

.283

.357

$(.074)$

.351

Graduate

$(.074)$

.133

$(.070)$

(.057)

.192

(.139)

.195

(.139)

.327

$(.203)$

.250

$(.067)$

.117

.113

(.104)

(.104)

.260

.136

Dad - College Graduate

.264

Mom Professional

(.134)

.268

$(.134)$

$(.156)$

$(.070)$

Dad Professional

.249

$(.086)$

.254

$(.087)$

.067

(.133)

.332

$(.203)$

Two Parent Family

.497

$(.070)$

.491

$(.070)$

.101

$(.134)$

.258

(.159)

.274

$(.065)$

.276

$(.065)$

.327

$(.060)$

.065

(.133)

Numerous Family Reading

Materials

$-.576$

(.153)

$-.570$

No Family Reading

$-.061$

County Population 1980:

$500,000-1,000,000$

$(.072)$

$(.153)$

.212

$(.068)$

.100

$(.134)$

County Population 1980:

$-.087$

(.080)

$-.066$

$(.073)$

$-.135$

(.084)

.322

$(.060)$

$>1,000,000$

$-.089$

$(.080)$

$-.248$

$(.080)$

.212

$(.068)$

Percentage of Families

on Welfare - County

$-2.373$

$(.627)$

$-2.859$

$(.761)$

$-.366$

(.079)

$-.139$

$(.084)$

1980

$\begin{array}{ll}- & .038\end{array}$

$(.068)$

.220

$(.564)$

$-.238$

$(.080)$

Catholic

Catholics / County

Population - 1980

.750

(.201)

.678

(.218)

$-.357$

(.079)

Catholic Schools /

Square Mile - County

.616

$(.543)$

$-1124.0$

$-1123.2$

$\begin{array}{cc}- & -.003 \\ - & (.093) \\ -.701 & -.258 \\ (.250) & -.203) \\ -1396.8 & (.249) \\ & -1396.0\end{array}$

.343

$(.572)$

Log Likelihood

$-1396.0$ 
Sample Graduation Rate

These analyseg are restricted to public school students in counties with populationg greater than 250,000. See notes below Table I for details concerning sample construction. 
Bivariate Probit Analysis of High School Graduation Students from Urban Counties

Table VI

Catholic School Attendance

Black

Female

Mom - High School Graduate

Dad - High School Graduate

Mom - College Graduate

Dad - College Graduate

Mom Professional

Dad Professional

Two Parent Family

Numerous Family Reading Materials

No Family Reading

Materials

County Population 1980: $500,000-1,000,000$

County Population 1980: $>1,000,000$

Percentage of Families on Welfare - County 1980

Catholic

Catholics / County Population - 1980

Catholic Schools / square Mile - County

Catholic school

Error Covariance

$$
\text { White }
$$

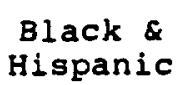

.124

(.081)

.076

$(.121)$

.180

$(.120)$

.147

(.133)

.194

$(.107)$

.032

(.151)

.106

(.095)

.070

(.113)

.128

(.096)

.215

$(.267)$

.104

(.105)

.093

(.109)

1.113

(.961)

1.034

(.092)

.199

$(.274)$

1.739

$(.534)$
(.121)

High School Graduation

.179
$(.157)$

White

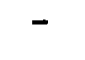

.100

$(.060)$

.368

(.073)

(.156)

.238

(.153)

.439

(.231)

.048

(.191)

$-.017$

(. 185$)$

.417

(.162)

.284

(.129)

.096

$-.602$

(.301)

.386

(.189)

.446

(.188)

1.148

(1.105)

.831

$(.140)$

.956

$(.485)$

.479

$(.400)$
.333

$(.073)$

.251

$(.139)$

.105

(.106)

.163

$(.120)$

.249

$(.087)$

.474

(.069)

.273

(.064)

$-.572$

(.147)

$-.053$

(.071)

$-.097$

$(.078)$

$-2.183$

$(.617)$

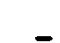

.608
$(.210)$$$
\text { - }
$$

Black \& Hispanic

.220

$(.062)$

.277

$(.056)$

.249

$(.069)$

.132

$(.072)$

.335

(.205)

.263

(.160)

.083

(.132)

.097

(.144)

.321

(.062)

.200

(.066)

$-.134$

(.086)

$-.246$

$(.082)$

$-.371$

$(.080)$

.052

$(.566)$

$-.595$

(.243)

.724

(.321)

1.122

(.686)

$-.237$

$-.125$

(.179) 
Mean - Dependent

Variable

Sample Size
.09

2626
.05

2434
.76

2626
.64

2434

See noteg below Table IV for sample construction rules. I also estimate models that relax the exclusion restrictions imposed above. For white students, I estimate separate models that include (i) religious affiliation, (ii) Catholic schools per square mile or (iii) both in the graduation equation. The estimates of Catholic school effects and their standard errors are $.798 / .476, .648 / .351$, and $.649 / .589$ respectively. For minority students, the alternative specifications include (i) religioug affiliation (ii) local Catholic population dengity or (iii) both. The corregponding results are $1.209 / .761,1.271 / .655$, and $1.356 / .716$ respectively. In all six cases, the estimated covariance between the error terms is negative although statistically insignificant. 
Predicted Grdauation Rates

for Public School students by county size

Whites

\section{County \\ Population}

Less than

250,000

$250,000-$

500,000

$500,000-$

$1,000,000$

$1,000,000+$
Predicted Graduation Rate - Public Schools

.83

.80

.79

.79
Fraction of Public School students

.56

.16

.16

.12
Fraction of

Catholic

School

Students

.26

.18

.33

.23

Blacks and Hispanics

$\begin{array}{lccc}\text { Less than } & .83 & .41 & .16 \\ 250,000 & & & .06 \\ 250,000- & .82 & .12 & .32 \\ 500,000 & & & \\ 500,000- & .75 & .21 & .46 \\ 1,000,000 & .69 & .26 & \end{array}$

The public school sample sizes are 5,434 for whites and 3,898 for minorities. The Catholic school sample sizes are 307 for whites and 139 for minorities. The predicted graduation rates are for public school students. These predicted gradution rates are constructed using coefficients from two probit models of high school graduation. The covariates include those used in Table IV. The representative student is assumed to be male with two parents who both have high school educations. The county welfare rate is assumed to be .1 . 
Probit Analysis of College Graduation students from Urban Counties

\section{Table VIII}

\section{WHITES}

Full Sample

Black

Female

Mom - High School

Graduate

Dad - High School Graduate

Mom - College

Graduate

Dad - College

Graduate

Mom Professional

Dad Professional

Two Parent Family

Numerous Family

Reading

Materials

No Family Reading

Materials

County Population

1980 :

$500,000-1,000,000$
High School

Graduates

.056

$(.058)$

.374

(.086)

.331

$(.085)$

.393

(.094)

.314

$(.078)$

.227

.454

$(.070)$

.139

(.079)

.304

$(.064)$

$-.579$

(.311)

$-.083$

$(.070)$
BLACKS \& HISPANICS

Full sample

$-.021$

(.077)

.102

$(.072)$

.281

$(.085)$

.024

$(.089)$

.587

(.163)

.344

(.138)

.166

(.134)

.257

(.122)

.132

$(.079)$

.262

(.079)

$-.229$

(.140)

$-.280$

(.101)
High School

Graduates

$-.109$

$(.085)$

.012

$(.079)$

.259

(.094)

$-.007$

(.098)

.470

(.172)

.322

(.147)

.175

(.145)

.260

$(.132)$

.037

(.089)

.236

$(.086)$

$-.207$

(.161)

$-.248$

(.110) 


\begin{tabular}{|c|c|c|c|c|}
\hline $\begin{array}{l}\text { County Population } \\
1980: \\
>1,000,000\end{array}$ & $\begin{array}{l}-.016 \\
(.079)\end{array}$ & $\begin{array}{l}-.015 \\
(.085)\end{array}$ & $\begin{array}{l}-.162 \\
(.097)\end{array}$ & $\begin{array}{l}-.072 \\
(.107)\end{array}$ \\
\hline $\begin{array}{l}\text { Percentage of } \\
\text { Families } \\
\text { on Welfare - County } \\
1980\end{array}$ & $\begin{array}{l}-.077 \\
(.600)\end{array}$ & $\begin{array}{l}.425 \\
(.649)\end{array}$ & $\begin{array}{l}.447 \\
(.737)\end{array}$ & $\begin{array}{l}.618 \\
(.833)\end{array}$ \\
\hline $\begin{array}{l}\text { Catholics / County } \\
\text { Population - } 1980\end{array}$ & $\begin{array}{l}1.042 \\
(.194)\end{array}$ & $\begin{array}{l}.977 \\
(.208)\end{array}$ & & \\
\hline $\begin{array}{l}\text { Catholic Schools / } \\
\text { Square Mile - County }\end{array}$ & - & & $\begin{array}{l}-.281 \\
(.318)\end{array}$ & $\begin{array}{l}-.283 \\
(.372)\end{array}$ \\
\hline Catholic School & $\begin{array}{l}.342 \\
(.096)\end{array}$ & $\begin{array}{l}.303 \\
(.102)\end{array}$ & $\begin{array}{l}.620 \\
(.134)\end{array}$ & $\begin{array}{l}.476 \\
(.141)\end{array}$ \\
\hline $\begin{array}{l}\text { Sample Graduation } \\
\text { Rate }\end{array}$ & .27 & .34 & .12 & .18 \\
\hline Sample Size & 2626 & 1991 & 2434 & 1554 \\
\hline
\end{tabular}

See notes below Table IV for sample construction rules. 
Table IX

Wage Effects of Catholic Schooling For Young Men

Dependent Variable - log (hourly wage)

Whites

Blacks and Hispanics

Catholic

$\begin{array}{ll}.065 & .050 \\ (.060) \quad(.055)\end{array}$

b

c

d

e

f

School

High School

Graduate

$\begin{array}{ll}.195 & .165 \\ (.036) & (.036)\end{array}$

.180

$(.033)$

.027
$(.055)$
.165
$(.036)$

$(.084)$

.272

.234

$.084)$

College
Graduate

R squared

.120

.145

.167

.121

.148

.158

The sample sizes are 1030 and 939 respectively. Each regression includes the background controls used in the bivariate probit analyses plus seven dummies for region of current residence, urban current residence, and interactions between urban and region. The wage observations come from 1990 and 1991. Respondents are included if they report a valid wage in either year. If a respondent reports a wage for both years, the wage is an average over the two years. Obviously, persons who are not interviewed in either yearly survey are excluded. Further, persons serving in the military during these two years are also excluded. All wages are measured in 1990 dollars. 
Descriptive statistics for Secondary students Residing in Urban Counties

Appendix Table A-1

Whites , Blacks \&

Black

Female

Mom - High School Graduate

Dad - High School Graduate

Mom - College Graduate

Dad - College Graduate

Mom Professional

Dad Professional

Two Parent Family

Numerous Family Reading Materials

No Family Reading Materials

Catholic

High School Graduate

College Graduate

County Population 1980:

$500,000-1,000,000$

County Population 1980:

$>1,000,000$

sample size

$$
\begin{gathered}
\text { Blacks \& } \\
\text { Hispancis }
\end{gathered}
$$$$
.57
$$

.50

.40

.38

.04

.06

.07

.07

.54

.28

.13

.42

.63

.11

.35

.44

2317
2398
PUBLIC SCHOOLS

CATHOLIC SCHOOLS

Whites

Blacks 8

Hispanics

.43

.61

.67

.79

.68

.16

.14

.19

.13

.27

.76

.50

.02

.75

.91

.37

.38

.55
.85

.44

.45

.32

228

Urban counties are defined as counties with more than 250,000 residents. See notes below Table IV for details concerning sample construction. 